\title{
Ontogenetic changes in DNA and RNA content of laboratory-reared Prochilodus lineatus larvae: use of RNA/DNA ratios as indicators of nutritional condition
}

\author{
M. V. Diaz ${ }^{\mathrm{A}, \mathrm{B}, \mathrm{E}}$, M. I. Gómez ${ }^{\mathrm{C}}$, S. Sánchez ${ }^{\mathrm{D}}$ and C. M. Fuentes ${ }^{\mathrm{C}}$ \\ A Instituto Nacional de Investigación y Desarrollo Pesquero (INIDEP), Paseo V. Ocampo 1, \\ Escollera Norte, Mar del Plata, B7602HSA, Buenos Aires, Argentina. \\ ${ }^{B}$ Instituto de Investigaciones Marinas y Costeras, Consejo Nacional de Investigaciones \\ Científicas y Técnicas (IIMyC-CONICET), Rodríguez Peña 4002-4100, Mar del Plata, \\ B7602GSD, Buenos Aires, Argentina. \\ ${ }^{C}$ Dirección de Pesca Continental, Ministerio de Agroindustria, Avenida Paseo Colón 982, \\ C1063ACJ, Ciudad Autónoma de Buenos Aires, Argentina.

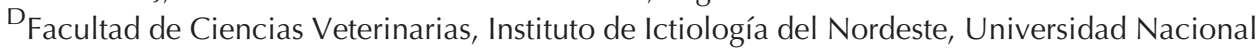 \\ del Nordeste. Consejo Nacional de Investigaciones Científicas y Técnicas (CONICET), \\ Sargento Cabral 2139, Corrientes, W3402BKG, Corrientes, Argentina. \\ ${ }^{\mathrm{E}}$ Corresponding author. Email: mdiaz@inidep.edu.ar
}

\begin{abstract}
The aims of the present study were to describe the ontogenetic performance of DNA and RNA content, as well as to assess the nutritional condition of Prochilodus lineatus larvae reared under different feeding treatments. The experiment consisted of two parts, the first 6-14 days after hatching (DAH) and the second 15-21 DAH. In the first part of the experiment, larvae were kept under one of two feeding treatments: fed or starved. During the second part of the experiment, larvae were kept under one of four treatments: fed, fed until 14 DAH and later starved, starved until $14 \mathrm{DAH}$ and fed later or starved. It is of note that the size and weight reached of larvae that were starved during early development and later received food were higher than those of than larvae in the other feeding treatments. In addition, instantaneous growth rates were higher and nutritional condition was better in larvae that were initially starved and fed later. The availability of food following a period of starvation seems to trigger larval metabolism and cellular division. Consequently, we recommend maintaining appropriate food provision in the aquaculture of $P$. lineatus larvae, especially in advanced developmental stages. We verified that RNA/DNA ratio is affected by the feeding condition and that it is sensitive enough to promptly reflect changes in feeding conditions of $P$. lineatus larvae. Thus, the RNA/DNA ratio could be used to assess nutritional condition of both wild and cultured $P$. lineatus larvae.
\end{abstract}

Additional keywords: fish larvae, fresh water, laboratory calibration, nucleic acids content, starvation.

Received 11 June 2017, accepted 9 October 2017, published online 12 January 2018

\section{Introduction}

The study of nutritional condition allows assessment of the physiological state of fish larvae, which reflects prevailing environmental conditions (Foley et al. 2016). Nutritional condition is an indicator of growth potential and can be effective in evaluating the survival chances of individual larvae (Yandi and Altinok 2015). Condition indices are useful tools for identifying favourable nursery areas, providing valuable information for comprehensive management of a population subject to overfishing, and could be taken into consideration to establish restricted areas and appropriate closure periods (Diaz et al. 2014). Nutritional condition indices have widely been used to determine the importance of starvation in larvae caught in the ocean (Buckley 1984; Robinson and Ware 1988; Clemmesen
1994). Nevertheless, studies on freshwater species are scarcer and, as suggested by Foley et al. (2016), studies examining RNA/DNA ratios in freshwater systems are needed. Moreover, results obtained in wild specimens always need to be calibrated under controlled experimental conditions, but such information is not always available because of rearing difficulties in many species (Hunter 1981; Uriarte and Balbontín 1987).

Many studies suggest that the RNA/DNA ratio and other derived indices are the best indicators of the nutritional status of various marine organisms (e.g. Clemmesen 1994; Bailey et al. 1995; Folkvord et al. 1996; Dahlhoff 2004; Chícharo and Chícharo 2008), and the RNA/DNA ratio is currently the most widely used biochemical indicator of the nutritional condition of fish larvae (Ma et al. 2015; Foley et al. 2016). The RNA/DNA 
ratio is an ecophysiological indicator that provides a measure of the capacity for synthesis of cells and is usually correlated with the nutritional status of individuals (Ferron and Leggett 1994; Buckley et al. 1999). The theoretical principle of using the RNA/DNA ratio is based on the fact that DNA content is virtually constant in somatic cells, so that tissue concentrations reflect the number of cells and are independent of nutritional status, whereas the amount of cellular RNA, mainly rRNA, available in the tissues is directly proportional to the level of protein synthesis (Clemmesen 1994). The RNA/DNA ratio varies with age, stage of development, size of the individual and changing environmental conditions (Bulow 1970). In addition, the RNA/DNA ratio has proved to be susceptible to environmental changes that affect the physiology of organisms, such as a low concentration of prey (McGurk et al. 1992; Chícharo and Chícharo 1995). Thus, organisms in good condition usually have higher RNA/DNA ratios than those that are in a poor condition (e.g. Robinson and Ware 1988; Clemmesen 1994).

The sábalo Prochilodus lineatus is a migratory fish that inhabits the Paraná and Uruguay rivers (South America), representing up to $60 \%$ of the fish biomass in flood plain lagoons (Bonetto et al. 1981; Bonetto 1986; Agostinho et al. 1993). Historically, this species constitutes the main target species in the fishery of the Lower Plata Basin (Quirós and Baigún 1985; Espinach Ros and Sánchez 2006; Baigún et al. 2008) and, over the past two decades, their captures have increased (Espinach Ros and Sánchez 2006; Baigún et al. 2013). The sábalo has been exported to China and Vietnam for aquaculture purposes (Kalous et al. 2012) and potentially would be subject to aquaculture production in the near future in other countries. As in the case of other migratory fish, $P$. lineatus spawn in a lotic environment and their larvae drift downriver through the main and secondary channels of the Paraná and Uruguay rivers until they enter the marginal flood plain lakes that act as nursery areas (Bonetto et al. 1981; Espinach Ros et al. 1998; Fuentes 1998; Fuentes et al. 2016). P. lineatus eggs have a mean diameter of $1.8 \mathrm{~mm}$ at an incubation temperature of $24-28^{\circ} \mathrm{C}$ and hatch after $17 \mathrm{~h}$ at $25^{\circ} \mathrm{C}$ (Sverlij et al. 1993). Hatched larvae range in size between 3.4 and $4.4 \mathrm{~mm}$, with a mean yolk sack diameter of $1.25 \mathrm{~mm}$ (Sverlij et al. 1993; Fuentes 1998). Larvae start feeding 5-6 days after hatching (DAH) when little yolk is still visible, and larval size ranges between 6.9 and $8.0 \mathrm{~mm}$. The preflexion phase ends when larvae are between 8.8 and $9.8 \mathrm{~mm}$ in size, when notochord flexion occurs (Sverlij et al. 1993). Sverlij et al. (1993) found that yolk absorption occurs up to 5-6 days at $24-28^{\circ} \mathrm{C}$ and that larvae could starve for at least 10 days before food was provided and survival was not compromised. Brown and Fuentes (2010) found that total yolk absorption in the wild occurred 6-7 DAH, and the drift period could last $\sim 1$ week after reserves are depleted. During that period, the larvae are unable to efficiently capture prey until they reach the lakes of the flood plain, where conditions for feeding are more favourable (Fuentes 1998; Paolucci et al. 2007). The available evidence indicates that the larval drift period surpasses total yolk absorption and larvae are exposed to certain starvation depending on the hydrological conditions.

In the present study we addressed the following hypotheses: (1) that the RNA/DNA ratio is affected by the feeding condition of $P$. lineatus larvae; and (2) that the RNA/DNA ratio in sensitive enough to reflect evolution and changes in $P$. lineatus larvae feeding condition. The main aims of the present study were to describe the ontogenetic performance of DNA and RNA content, as well as to assess the nutritional condition of $P$. lineatus larvae reared under different feeding treatments resembling regular and extreme hydrological regimes in the wild. We provide the necessary laboratory calibration for the future use of the RNA/DNA ratio to assess the condition of wild and cultured $P$. lineatus larvae.

\section{Materials and methods}

\section{Experimental design}

Larvae were obtained by controlled reproduction from one pair of adult $P$. lineatus from the Instituto de Ictiología del Nordeste (Corrientes, Argentina). Spawning was induced by injection of pituitary extract from the same species ( 5 and $1.5 \mathrm{mg}$ pituitary gland $\mathrm{kg}^{-1}$ bodyweight in females and males respectively).

Hatching took between 14 and $16 \mathrm{~h}\left(25-26^{\circ} \mathrm{C}\right)$. On Day 1 after hatching, larvae were randomly distributed across 18 acrylic fish aquaria (volume 1.5 L); between 200 and 300 larvae were placed in each aquarium, reaching a mean $( \pm$ s.d.) density of $0.17 \pm 0.05$ larvae $\mathrm{cm}^{-3}$. Each aquarium received a constant water flow to allow $50 \%$ of daily water renewal. Water temperature ranged between 22 and $24^{\circ} \mathrm{C}$ throughout the experiment. After total yolk absorption at $6 \mathrm{DAH}$, larvae were randomly assigned to two feeding regimes: those that were fed daily (nine aquaria) or unfed or starved larvae (nine aquaria). Larvae from the fed treatment groups were fed daily with Artemia salina nauplii at a density of 2-4 nauplii $\mathrm{cm}^{-3}$, which ensured stomach repletion and minimised excess uneaten food on the bottom of the aquaria, which was rare and was removed daily, along with dead fish larvae. Despite the attention paid to aquaria maintenance, after Days 15-16 we noted that some larvae from the starved treatment occasionally fed on some rotifers that were associated with organic particles on the bottom or on the wall of the aquaria. Even though complete starvation could not be achieved, we considered that this undesired phenomenon did not represent a serious issue for our objectives because larvae from the starved aquaria showed clear signs of suboptimal condition towards the end of the experiment. Every day, larvae were randomly sampled from three aquaria per feeding regime after yolk absorption. In all cases, aquaria were randomly chosen during the first 3 days (aquaria were not repeated within this period). After yolk absorption, the combination of aquaria was systematically alternated until the end of the experiment, sampling from each triad every 3 days. In this way, none of the tanks was overexploited and each maintained a representative population. The experiment started $6 \mathrm{DAH}$ and ended on Day 21 , because larval densities in most of the tanks were insufficient to continue. As mentioned previously, under regular hydrological conditions $P$. lineatus larvae starve approximately until 14 $\mathrm{DAH}$, so this day was chosen to switch feeding treatments: specifically, at $14 \mathrm{DAH}$, three of the fed aquaria were switched to the starved treatment and three of the starved aquaria were switched to the fed treatment (Fig. 1). Thus, the experiment consisted of two parts: the first 6-14 DAH and the second 15-21 $\mathrm{DAH}$. In the first part of the experiment larvae were reared under 


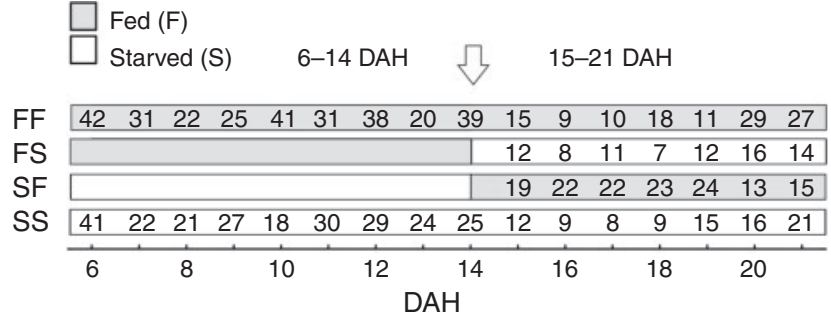

Fig. 1. Schematic diagram showing the feeding regimens for Prochilodus lineatus larvae. Numbers inside the bars indicate the number of larvae analysed from the different treatment groups. DAH, days after hatching. The arrow indicates the end of the first part of the experiment (6-14 DAH) and the start of the second part of the experiment (15-21 DAH).

two feeding regimens: fed (F) and unfed or starved (S); during the second part of the experiment, larvae were reared under four regimens: (1) fed during the entire experiment (FF); (2) fed until 14 DAH and then starved (FS); (3) starved until 14 DAH and then fed (SF); and (4) starved during the entire experiment (SS).

Every day, $\sim 20$ larvae were anaesthetised using benzocaine $(50 \mathrm{ppm})$ and frozen in liquid nitrogen. Larvae were thawed in the laboratory, photographed and measured. Standard length (SL) was measured to the nearest $0.01 \mu \mathrm{m}$ using a Carl Zeiss stereoscope equipped with Axio Vision software (Carl Zeiss, Oberkochen, Germany). The head was dissected according to Olivar et al. (2009). Muscular trunks were placed individually in Eppendorf tubes and freeze dried over a period of $24 \mathrm{~h}$. Larvae were weighed (dry weight, DW) using a Sartorius microbalance (Sartorius AG, Goettingen, Germany) to the nearest microgram and stored at $-80^{\circ} \mathrm{C}$ until analyses were performed. A total of 1031 larvae was analysed. The minimum dry mass for which reliable standardised RNA/DNA ratios (sRDRs) were obtained was $33 \mu \mathrm{g}$; thus, some results were dismissed because of a small amount of sample, with the remaining 951 RDs being confident determinations (Fig. 1).

\section{Analytical protocol}

For the assessment of larval nutritional status, the concentrations of nucleic acids per larva were quantified following the protocol described by Caldarone et al. (2001) with modifications made by Diaz and Pájaro (2012). This method is based on quantification of total nucleic acids (TNA) by spectrum fluorescence, RNA digestion by RNAse and subsequent determination of the fluorescence of the resulting DNA. Thus, RNA fluorescence is determined as the difference between TNA and DNA:

$$
[\mathrm{RNA}]=[\mathrm{TNA}]-[\mathrm{DNA}]
$$

For nucleic acid extraction, cells were disrupted by the addition of $1 \%$ Sarkosyl Tris EDTA (TES). Samples were centrifuged at $15314 \mathrm{~g}$ for $15 \mathrm{~min}$ at $2^{\circ} \mathrm{C}$ on a microcentrifuge. Subsequently, a $100-\mu \mathrm{L}$ aliquot of the supernatant was placed in disposable spectrofluorometer cuvette with Tris EDTA buffer (TE) $(850 \mu \mathrm{L})$ to make up a total volume of $950 \mu \mathrm{L}$. Thus, the concentration of TES in the samples was $0.05 \%$. Fluorescence measurements were made using a PerkinElmer spectrofluorometer (PerkinElmer LAS, Rodgau, Germany) with excitation and emission wavelengths of 360 and $590 \mathrm{~nm}$ respectively. Prior to measuring fluorescence, $50 \mu \mathrm{L}$ of ethidium bromide $\left(0.1 \mathrm{mg} \mathrm{mL}^{-1}\right)$ was added to each cuvette. The first reading correspond to the fluorescence of DNA + RNA; then, $50 \mu \mathrm{L}$ of RNAse $\left(20 \mathrm{U} \mathrm{mL}^{-1}\right)$ was added and samples were incubated for 30 min at $42^{\circ} \mathrm{C}$, after which a second reading was taken, corresponding to the DNA. The fluorescence values obtained are correlated with the nucleic acid concentrations present in each larva. Calibration curves were constructed for the nucleic acids using ultrapure solutions, using known concentrations of both DNA (lambda DNA, digested with HindIII; 10236250001; Roche Diagnostics IT Solutions, Berlin, Germany) and RNA (RNA 16S-23S from Escherichia coli; 10206938001; Roche).

Once the larval DNA and RNA content had been determined, RNA/DNA ratios (RDR) were calculated. The RDR were standardised (sRDR) as described by Caldarone et al. (2006); thus, the sRDR values can be compared with other data in the literature. In this way, we used 2.40 as the reference value of the slope of the calibration curves for the DNA and RNA ultrapure standards and the mean $( \pm$ s.d.) slope of the calibration curves was $3.07 \pm 0.61$. Results are expressed as micrograms of DNA per milligram dry weight, micrograms of RNA per milligram dry weight and sRDR. Growth at the end of the two experimental periods was determined by the specific growth rate (SGR; \% day ${ }^{-1}$ ) and determined using the following equation (Hopkins 1992):

$$
\mathrm{SGR}=100 \times\left(\ln S L_{\mathrm{f}}-\ln S L_{\mathrm{i}}\right) \div \Delta t
$$

where $S L_{\mathrm{f}}$ and $S L_{\mathrm{i}}$ are the final and initial fish SL (mm) respectively and $\Delta t$ is the time between sampling intervals (i.e. 9 days for the first part of the experiment and 15 days for the second).

The variation in the SRDR was used as an indicator of larval condition from feeding treatments at the end of the two experimental periods. Thus, the change in sRDR (VRDs) was calculated as follows:

$$
\mathrm{VRDs}=100 \times\left(s R D R_{\mathrm{f}}-s R D R_{\mathrm{i}}\right) \div s R D R_{\mathrm{i}}
$$

where $s R D R_{\mathrm{i}}$ is the sRDR on Day 6 after hatching and $s R D R_{\mathrm{f}}$ is the sRDR at the end of both parts of the experiment (i.e. 14 and $21 \mathrm{DAH})$.

\section{Statistical analysis}

Unless indicated otherwise, data are presented as the median and median absolute deviation (MAD), and analyses were performed using INFOSTAT (2016 version, Grupo InfoStat, Universidad Nacional de Córdoba, Córdoba, Argentina). The level of significance was set at two-tailed $P<0.001$. Because the data did not meet analysis of variance (ANOVA) assumptions of normal distribution and homogeneous variance, non-parametric Kruskal-Wallis tests were used, followed by multiple comparisons. Median larval length, weight, nucleic acid contents, SGR and VRDs between the start and end of each part of the experiment in each feeding treatment group were compared (i.e. 6-14 DAH and 15-21 DAH). 

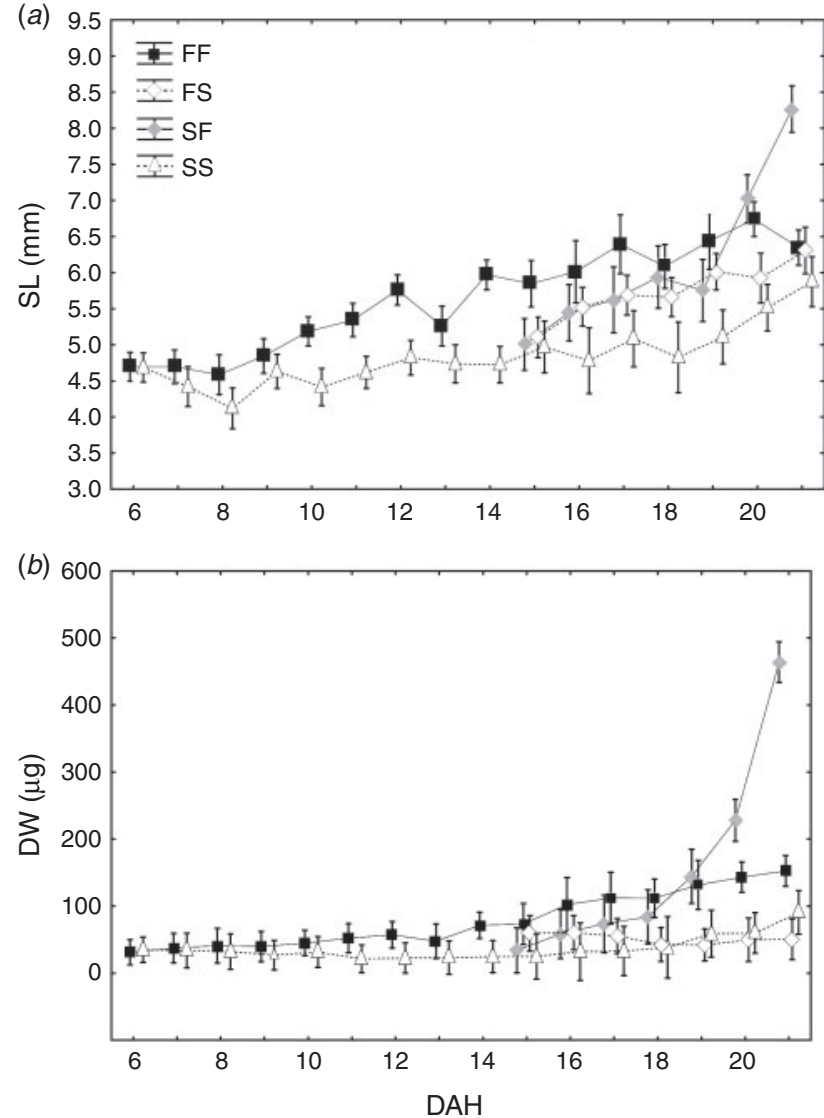

Fig. 2. Ontogenetic changes in (a) standard length (SL) and $(b)$ dry weight (DW) of Prochilodus lineatus larvae from the different feeding regimens. Data are the mean \pm s.d. DAH, days after hatching; $F$, fed during the entire experiment; FS, fed until 14 DAH and then starved; SF, starved until $14 \mathrm{DAH}$ and then fed; SS, starved during the entire experiment.

\section{Results}

\section{Morphological development and growth}

On 6 DAH, when the experiment started, the mean ( \pm s.d.) SL for $P$. lineatus larvae was $4.68 \pm 0.38 \mathrm{~mm}$. It is important to mention that no shrinkage corrections due to fixation in liquid nitrogen were made in the larval sizes reported herein because of the lack of information in this regard for $P$. lineatus larvae. Gómez et al. (2014) reported between 2 and $6 \%$ shrinkage due to formalin fixation of $P$. lineatus larvae; they reported a mean fresh length of $5.3 \mathrm{~mm} 6 \mathrm{DAH}$, at which time we registered a mean size of $4.68 \mathrm{~mm}$ SL. Thus, larvae shrank $\sim 12 \%$ after fixation in liquid nitrogen. Thus, herein we report results in relation to age rather than size to avoid fixation effects on larval length.

The median daily SL and DW of fed larvae were generally greater than those for starved larvae. The increase in DW was especially accelerated from $18 \mathrm{DAH}$ after the larvae reached the flexion stage. A particularly rapid increase in mean SL and DW was observed for larvae from the SF group after food was provided on 14 DAH (Fig. 2). The median DW obtained for larvae in the SF group increased exponentially from $83.00 \mu \mathrm{g}$ (MAD 20.50) on 18 DAH to $449.00 \mu \mathrm{g}$ (MAD 193.00) on 21

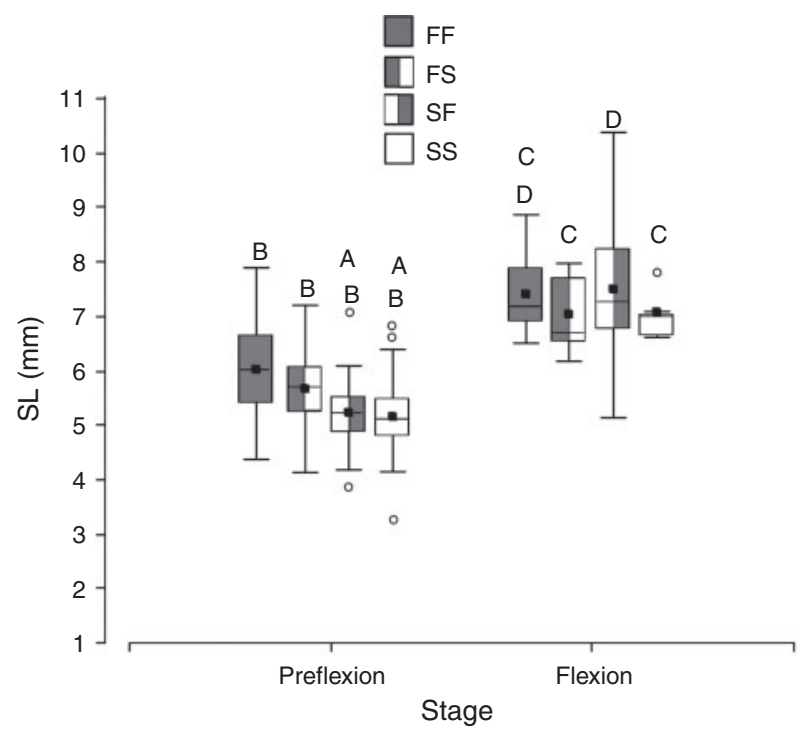

Fig. 3. Box plots showing the standard length (SL) obtained for each developmental stage of Prochilodus lineatus larvae from feeding treatments. The boxes show the interquartile range ( 25 th -75 th percentiles), with the median value indicated by the horizontal line; whiskers show the range. The closed squares indicate mean values and open circles show outliers. Different letters indicate significant differences among feeding treatments within a developmental stage ( $P<0.001$, a posteriori Tukey's test). FF, fed during the entire experiment; FS, fed until 14 days after hatching (DAH) and then starved; SF, starved until 14 DAH and then fed; SS, starved during the entire experiment.

DAH (Fig. $2 b$ ). At the end of the experiment, larvae from the SF group were significantly larger and heavier than those in the other groups $(H=27.75 ; P<0.001 ;$ Fig. 2$)$.

On Day 6 after hatching, the first day of sampling, larvae were in the preflexion phase and yolk reserves were completely depleted. Notochord flexion occurred during the second part of the experiment and started on Day 16 in all the treatment groups except the SS group, in which flexion larvae were detected just on $21 \mathrm{DAH}$. The median length of flexion larvae was significantly larger than that of preflexion larvae (Fig. 3). The highest median SL values were found for SF larvae, but the highest variability was also observed within this feeding treatment (median SL 7.44 mm; MAD 0.61).

\section{Ontogenetic changes in nucleic acid content}

Ontogenetic changes in DNA and RNA content per larva throughout the experiment are shown in Fig. 4, whereas median values and MAD are given in Table 1 . There was a gradual increase in DNA and RNA content per larva until 18 DAH in all feeding treatments. After that, rapid increases in DNA and RNA content were observed. In particular, the DNA and RNA content per larva increased rapidly in larvae in the SF group between 18 and $21 \mathrm{DAH}$. Ontogenetic changes in DNA and RNA content relative to DW ( $\mu \mathrm{g} \mathrm{mg}^{-1} \mathrm{DW}$; Fig. 5; Table 1 ) showed a quite different pattern than those on an individual fish basis. DNA content was higher for starved larvae, increasing slightly between 6 and 12 DAH and decreasing gradually between 12 and $16 \mathrm{DAH}$, then peaking on $18 \mathrm{DAH}$. A similar pattern was 

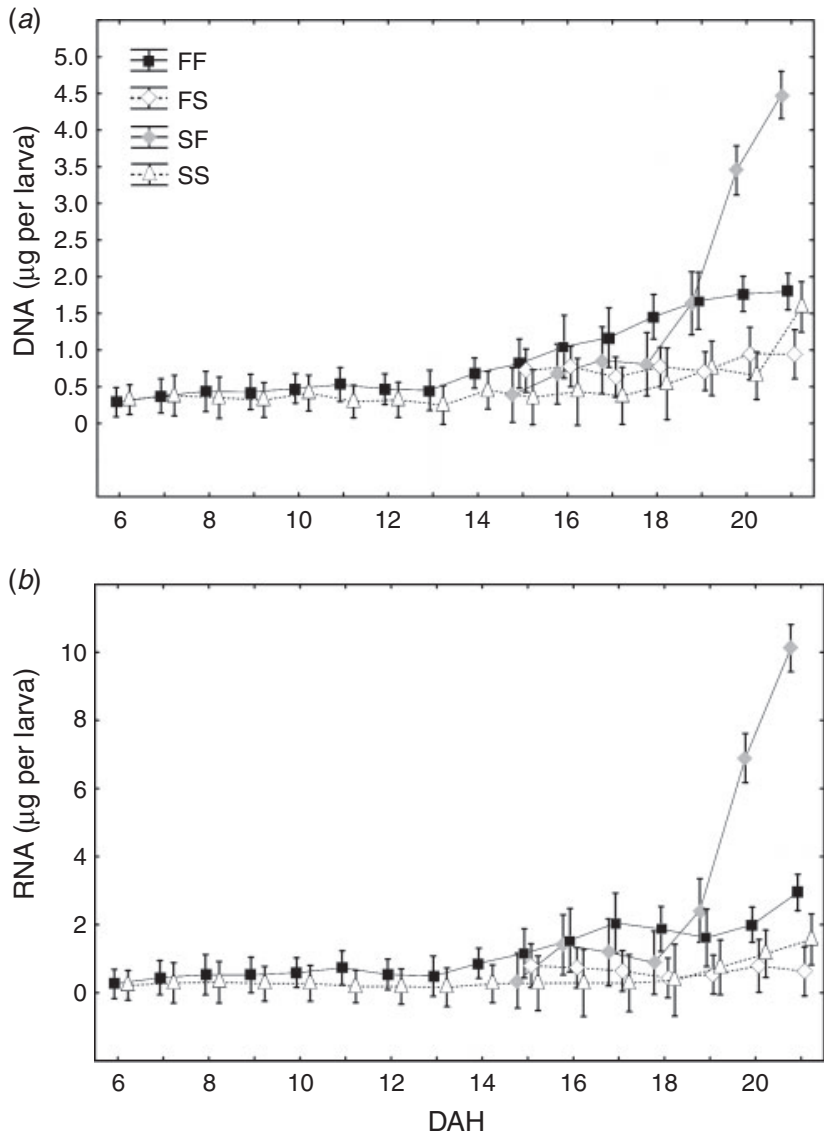

Fig. 4. Ontogenetic changes in (a) DNA and (b) RNA content per Prochilodus lineatus larvae in the different feeding treatments. Data are the mean \pm s.d. DAH, days after hatching; FF, fed during the entire experiment; FS, fed until 14 DAH and then starved; SF, starved until $14 \mathrm{DAH}$ and then fed; SS, starved during the entire experiment.

observed for RNA content, but with a peak on Day 20 for larvae in the SF group.

\section{Ontogenetic changes in RDR}

Except for Day 6 after hatching $(H=3.73 ; P=0.053)$, the sRDR was significantly higher for fed larvae $(P<0.001$; Fig. 6; Table 1) during the first part of the experiment (6-14 DAH). Within this period, the sRDR increased slightly from 0.62 (MAD 0.12) to 1.11 (MAD 0.18) for fed larvae, but was relatively steady in starved larvae, from 0.54 (MAD 0.18 ) to 0.48 (MAD 0.09). No significant differences were observed for median sRDR for starved larvae during this period $(H=-1.39$; $P>0.05)$. In the second part of the experiment, the median sRDR obtained for larvae from the SF group was greater than that in the other treatment groups, with median sRDR increasing from 0.62 (MAD 0.24) to 1.93 (MAD 0.28) between 15 and 21 $\mathrm{DAH}$ in the SF group. Within this period, no significant differences in median sRDR were observed for larvae in the FF group $(H=6.40 ; P=0.379)$. Larvae from the $\mathrm{FS}$ and $\mathrm{SS}$ groups had slight differences in median sRDR only between Days 15 and 21 after hatching $(H=21.36(P=0.0016)$ and $H=20.95$ $(P=0.0019)$ respectively).

\section{SGR and VRDs}

The median SGR (Fig. 7a) of fed larvae during the first part of the experiment was $3.04 \%$ day $^{-1}$ (MAD 1.10), significantly higher than the median SGR of starved larvae $\left(0.02 \%\right.$ day $^{-1}$ (MAD 0.41); $H=37.12 ; P<0.0001)$. In the second part of the experiment, between 15 and $21 \mathrm{DAH}$, the SGR of larvae in SF group was $3.99 \%$ day $^{-1}$ (MAD 0.72), significantly higher than that of larvae in the other groups $(H=27.73 ; P<0.0001)$.

The median VRDs (Fig. $7 b$ ) of fed larvae during the first part of the experiment was $80 \%$ (MAD 28), significantly higher than the value for starved larvae ( $-0.50 \%$ (MAD 19.50); $H=22.22$; $P<0.001)$. In the second part of the experiment, the VRDs of larvae in the SF group was $243 \%$ (MAD 48), significantly higher than that of larvae in the other groups $(H=46.14 ; P<0.0001)$. The sRDR values for larvae in the FS group decreased from 15 to $21 \mathrm{DAH}$, resulting in a negative VDRs of $-58 \%$ (MAD 9).

\section{Discussion}

The results of the present study provide evidence that the RDR is a good indicator of the feeding condition of $P$. lineatus larvae; it also promptly reflects changes in larval feeding status of the species. In addition, the RDR results are feasible and can be used in tank-reared larvae, showing great potential and many possible applications. For example, RDR could represent an excellent tool to determine the quality of larvae produced, to help plan feeding programs or to adjust rations for larvae for aquaculture purposes. The RDR could also be used to measure the effect of different feed ingredients on larval digestive physiology, especially to determine whether at any time certain live or dry food items are insufficient to meet fish needs, because the point at which the RDR declines can be determined before nutritional deficiencies translate into a loss in live weight gain or larval mortality. In addition, the results of the present study provide the necessary laboratory calibrations of for the RDR against extreme and changing food supply scenarios to be used for estimating the incidence of starvation in the wild.

We observed a gradual increase in the length, weight and nucleic acid contents per larva in the first part of the experiment, which reflects the typical dynamic of metabolism of early larval developmental stages. When cell numbers increase, the amount of DNA increases (hyperplasia), but when cell size increases the amount of DNA stays stable (hypertrophy; Gwak et al. 2003; Malzahn et al. 2003). A trend for decreased DNA content was observed between 12 and $14 \mathrm{DAH}$, a fact that we attributed to a switch from a higher proportion of hyperplasia in small fish to a higher proportion of hypertrophy in larger fish, which is consistent with results reported in previous studies of marine fish larvae (Buckley et al. 1999; Malzahn et al. 2003; Fonseca et al. 2006). This trend was evident for starved larvae that switched to being fed in the second part of the experiment (SF group).

The results of the present study show that starved individuals tend to have lower growth rates and lower RDR than fed specimens, which is consistent with previous studies conducted using larvae of marine fish (Dahlhoff 2004; Tanaka et al. 2008; Foley et al. 2016). A remarkable result of the present study is that the RDR values recorded were generally lower than those reported in the literature for marine fish larvae, which typically range between 1.0 and 3.0 (Ferron and Leggett 1994). Even fed 
Table 1. Median DNA and RNA content per Prochilodus lineatus larva and per dry weight (DW), as well as standardised RNA/DNA ratios (SRDR) in the different groups

Data show median values, with the median absolute deviation in parentheses. DAH, days after hatching; F, fed; S, starved; FF, fed during the entire experiment; FS, fed until 14 DAH and then starved; SF, starved until 14 DAH and then fed; SS, starved during the entire experiment

\begin{tabular}{|c|c|c|c|c|c|c|c|}
\hline Treatment & DAH & $\begin{array}{c}\text { Number of } \\
\text { samples analysed }\end{array}$ & $\begin{array}{c}\text { RNA } \\
\text { ( } \mu \mathrm{g} \text { per larva) }\end{array}$ & $\begin{array}{c}\text { DNA } \\
(\mu \mathrm{g} \text { per larva })\end{array}$ & $\begin{array}{c}\text { RNA } \\
\left(\mu \mathrm{gg}^{-1} \mathrm{DW}\right)\end{array}$ & $\begin{array}{c}\text { DNA } \\
\left(\mu \mathrm{mg}^{-1} \mathrm{DW}\right)\end{array}$ & sRDR \\
\hline \multirow[t]{9}{*}{$\mathrm{F}$} & 6 & 42 & $0.21(0.06)$ & $0.27(0.07)$ & $116.46(35.07)$ & $33.41(3.04)$ & $0.62(0.12)$ \\
\hline & 7 & 31 & $0.40(0.11)$ & $0.40(0.04)$ & $108.01(43.69)$ & $28.71(9.22)$ & $0.78(0.14)$ \\
\hline & 8 & 22 & $0.50(0.22)$ & $0.40(0.10)$ & $125.40(31.99)$ & $34.92(7.66)$ & $0.90(0.15)$ \\
\hline & 9 & 25 & $0.32(0.18)$ & $0.36(0.14)$ & $87.15(26.72)$ & $33.69(6.59)$ & $0.88(0.12)$ \\
\hline & 10 & 41 & $0.51(0.06)$ & $0.46(0.10)$ & $162.39(49.47)$ & $32.66(8.82)$ & $0.74(0.08)$ \\
\hline & 11 & 31 & $0.67(0.28)$ & $0.55(0.15)$ & $133.83(25.05)$ & $36.53(1.97)$ & $0.70(0.16)$ \\
\hline & 12 & 38 & $0.50(0.22)$ & $0.53(0.17)$ & 77.78 (30.59) & $24.84(6.76)$ & $0.97(0.14)$ \\
\hline & 13 & 20 & $0.36(0.14)$ & $0.44(0.23)$ & $70.20(7.65)$ & $24.61(5.45)$ & $0.86(0.18)$ \\
\hline & 14 & 39 & $0.70(0.32)$ & $0.52(0.19)$ & $52.52(36.63)$ & $18.59(5.47)$ & $1.11(0.18)$ \\
\hline \multirow[t]{9}{*}{$\mathrm{S}$} & 6 & 41 & $0.14(0.05)$ & $0.29(0.06)$ & $65.89(16.13)$ & $29.28(3.90)$ & $0.54(0.18)$ \\
\hline & 7 & 22 & $0.23(0.13)$ & $0.36(0.11)$ & $103.47(5.12)$ & 41.09 (7.03) & $0.47(0.17)$ \\
\hline & 8 & 21 & $0.29(0.12)$ & $0.39(0.06)$ & $78.96(16.11)$ & $31.16(11.48)$ & $0.68(0.24)$ \\
\hline & 9 & 27 & $0.22(0.05)$ & $0.26(0.10)$ & $103.24(26.77)$ & $42.18(3.58)$ & $0.48(0.07)$ \\
\hline & 10 & 18 & $0.28(0.10)$ & $0.39(0.13)$ & $78.50(18.89)$ & $42.41(4.44)$ & $0.35(0.16)$ \\
\hline & 11 & 30 & $0.13(0.02)$ & $0.30(0.03)$ & $62.85(28.29)$ & $44.86(7.53)$ & $0.31(0.10)$ \\
\hline & 12 & 29 & $0.17(0.04)$ & $0.32(0.02)$ & $82.78(7.01)$ & $41.63(9.36)$ & $0.47(0.08)$ \\
\hline & 13 & 24 & $0.12(0.03)$ & $0.27(0.04)$ & $47.74(18.25)$ & $32.17(10.61)$ & $0.47(0.08)$ \\
\hline & 14 & 25 & $0.21(0.08)$ & $0.39(0.14)$ & $9.10(4.73)$ & $23.12(13.34)$ & $0.48(0.09)$ \\
\hline \multirow[t]{7}{*}{$\mathrm{FF}$} & 15 & 15 & $0.80(0.36)$ & $0.74(0.30)$ & $20.79(8.02)$ & $15.07(3.94)$ & $0.89(0.28)$ \\
\hline & 16 & 9 & $1.33(0.73)$ & $1.04(0.29)$ & $13.03(2.36)$ & $9.65(1.10)$ & $1.10(0.05)$ \\
\hline & 17 & 10 & $1.58(0.97)$ & $1.00(0.48)$ & $14.87(5.61)$ & $9.75(2.33)$ & $1.17(0.39)$ \\
\hline & 18 & 18 & $1.89(0.92)$ & $1.42(0.79)$ & $35.35(24.19)$ & $22.13(9.79)$ & $1.01(0.37)$ \\
\hline & 19 & 11 & $1.29(0.53)$ & $1.90(0.46)$ & $11.72(3.34)$ & $14.73(3.13)$ & $0.91(0.42)$ \\
\hline & 20 & 29 & $1.48(0.77)$ & $1.28(0.67)$ & $12.90(4.63)$ & $11.21(3.60)$ & $0.99(0.30)$ \\
\hline & 21 & 27 & $1.64(0.70)$ & $1.25(0.67)$ & $18.06(4.26)$ & $11.24(1.69)$ & $1.36(0.58)$ \\
\hline \multirow[t]{7}{*}{ FS } & 15 & 12 & $0.39(0.23)$ & $0.71(0.34)$ & $17.10(8.62)$ & $13.71(3.15)$ & $0.89(0.35)$ \\
\hline & 16 & 8 & $0.66(0.26)$ & $0.76(0.29)$ & $12.54(3.90)$ & $13.29(4.08)$ & $0.79(0.24)$ \\
\hline & 17 & 11 & $0.42(0.24)$ & $0.57(0.29)$ & $58.81(47.84)$ & $35.92(7.85)$ & $0.52(0.20)$ \\
\hline & 18 & 7 & $0.42(0.12)$ & $0.62(0.35)$ & $59.62(30.29)$ & $35.21(20.39)$ & $0.52(0.10)$ \\
\hline & 19 & 12 & $0.35(0.15)$ & $0.66(0.21)$ & $42.51(29.29)$ & $32.85(18.18)$ & $0.53(0.06)$ \\
\hline & 20 & 16 & $0.70(0.49)$ & $0.88(0.19)$ & $14.60(5.61)$ & $22.39(11.37)$ & $0.68(0.27)$ \\
\hline & 21 & 14 & $0.39(0.21)$ & $0.88(0.39)$ & $7.78(2.23)$ & $16.25(6.08)$ & $0.50(0.08)$ \\
\hline \multirow[t]{7}{*}{ SF } & 15 & 19 & $0.16(0.03)$ & $0.32(0.10)$ & $45.37(30.32)$ & $25.34(16.41)$ & $0.62(0.24)$ \\
\hline & 16 & 22 & $0.77(0.42)$ & $0.45(0.16)$ & 39.79 (25.74) & $15.98(2.78)$ & $1.45(0.44)$ \\
\hline & 17 & 22 & $1.18(0.42)$ & $0.84(0.15)$ & $18.46(12.80)$ & $15.54(7.13)$ & $1.16(0.38)$ \\
\hline & 18 & 23 & $1.03(0.57)$ & $0.52(0.19)$ & $14.42(2.87)$ & $12.52(0.93)$ & $1.38(0.31)$ \\
\hline & 19 & 24 & $1.14(0.54)$ & $1.73(0.85)$ & $18.32(4.40)$ & $11.83(1.20)$ & $1.32(0.42)$ \\
\hline & 20 & 13 & $5.60(2.76)$ & $3.70(0.99)$ & $34.34(17.00)$ & $16.94(14.33)$ & $2.01(0.51)$ \\
\hline & 21 & 15 & $7.82(3.22)$ & $3.81(1.23)$ & $21.58(1.53)$ & $11.24(1.63)$ & $1.93(0.28)$ \\
\hline \multirow[t]{7}{*}{ SS } & 15 & 12 & $0.19(0.08)$ & $0.38(0.06)$ & $17.98(12.38)$ & $35.16(11.99)$ & $0.50(0.24)$ \\
\hline & 16 & 9 & $0.09(0.05)$ & $0.26(0.09)$ & $14.78(4.27)$ & $21.48(16.23)$ & $0.19(0.07)$ \\
\hline & 17 & 8 & $0.24(0.14)$ & $0.41(0.03)$ & $67.98(38.61)$ & $38.46(3.03)$ & $0.54(0.09)$ \\
\hline & 18 & 9 & $0.47(0.23)$ & $0.42(0.10)$ & $14.79(9.93)$ & $19.08(8.65)$ & $0.98(0.70)$ \\
\hline & 19 & 15 & $0.69(0.54)$ & $0.54(0.11)$ & $25.22(13.13)$ & $16.40(10.19)$ & $0.87(0.40)$ \\
\hline & 20 & 16 & $0.84(0.41)$ & $0.48(0.17)$ & $25.78(14.45)$ & $14.94(7.04)$ & $1.15(0.22)$ \\
\hline & 21 & 21 & $1.08(0.36)$ & $1.02(0.31)$ & $39.09(19.83)$ & $30.36(13.69)$ & $1.15(0.31)$ \\
\hline
\end{tabular}

larvae had median RDR values $<1.0$ in the first part of the experiment, although the DNA and RNA content was similar to that of other species of larvae at similar developmental stages (Gwak et al. 2003; Tanaka et al. 2008; Olivar et al. 2009). The reduced RDR value in $P$. lineatus larvae is consistent with the conclusions of Houde and Zastrow (1993) in that, on average, larger eggs in freshwater species confer certain resistance to starvation to their larvae, which probably could also be linked to a lower metabolism compared with marine fish larvae.

It is of note that larvae exposed to starvation during early development but subsequently fed (SF) reached higher sizes, weights, instantaneous growth rates and nutritional condition than larvae from other feeding treatments, even those that were fed throughout the experiment (FF group). This indicates an 

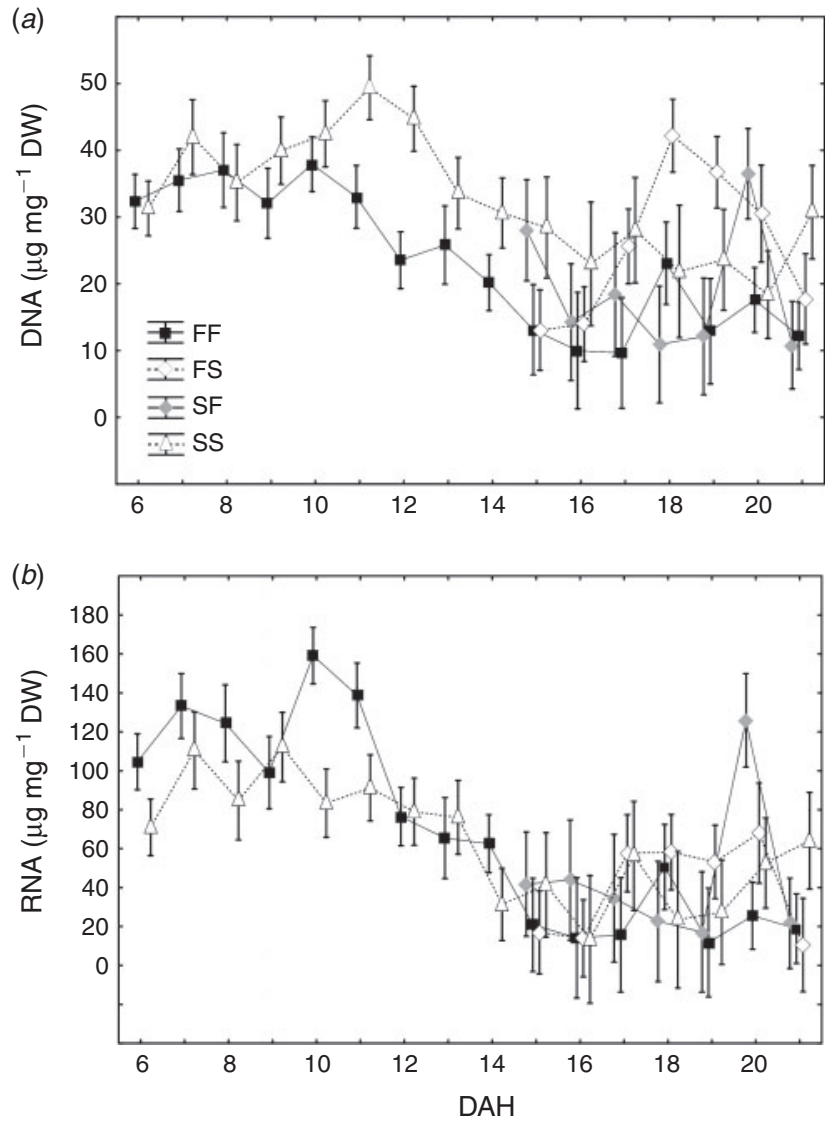

Fig. 5. Ontogenetic changes in (a) DNA and (b) RNA content per dry weight (DW) of Prochilodus lineatus larvae in the different feeding treatments. Data are the mean \pm s.d. DAH, days after hatching; FF, fed during the entire experiment; FS, fed until 14 DAH and then starved; SF, starved until $14 \mathrm{DAH}$ and then fed; SS, starved during the entire experiment.

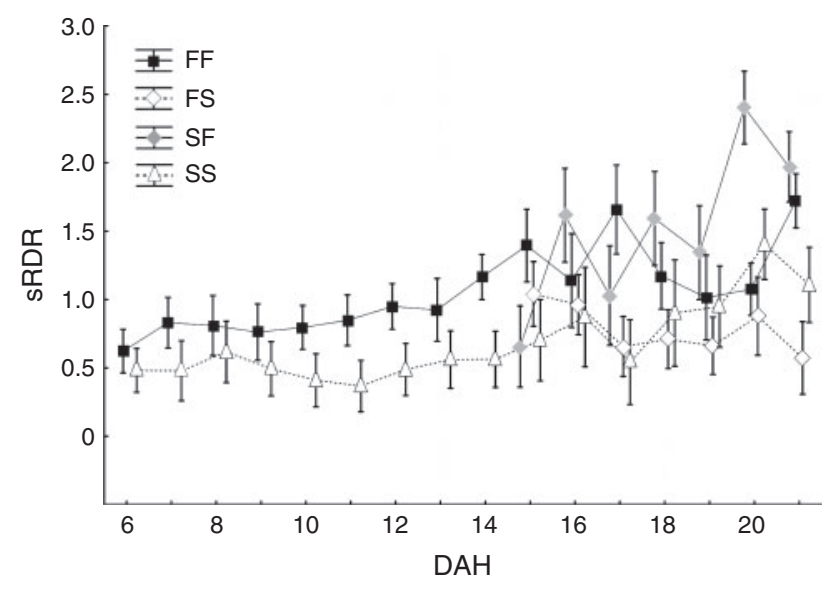

Fig. 6. Ontogenetic changes in standardised RNA/DNA ratios (sRDR) of Prochilodus lineatus larvae in the different feeding treatments. Data are the mean \pm s.d. DAH, days after hatching; FF, fed during the entire experiment; FS, fed until 14 DAH and then starved; SF, starved until 14 DAH and then fed; SS, starved during the entire experiment.
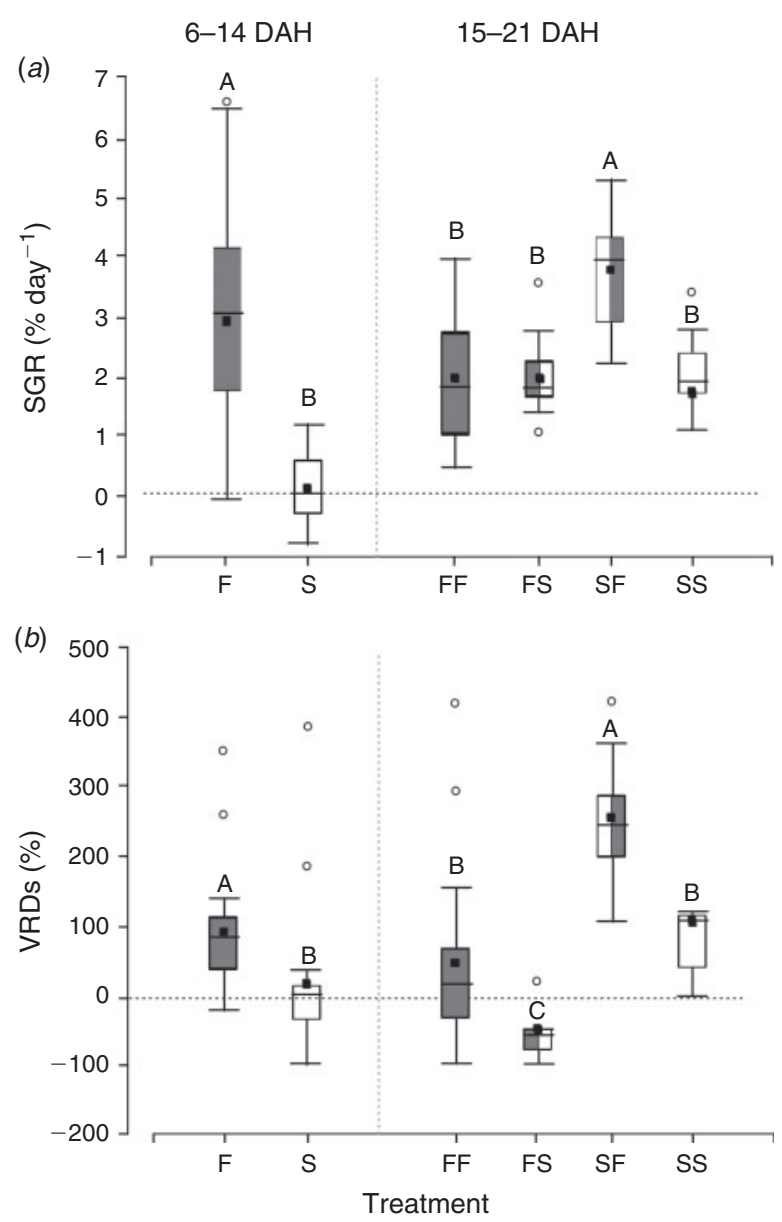

Fig. 7. (a) Specific growth rate (SGR) and (b) variation in RNA/DNA ratios (VRDs) of Prochilodus lineatus larvae in the different feeding treatments during the first part of the experiment (6-14 days after hatching (DAH)) and the second part of the experiment (15-21 DAH). The boxes show the interquartile range ( 25 th -75 th percentiles), with the median value indicated by the horizontal line; whiskers show the range. The closed squares indicate mean values and open circles show outliers. Different letters indicate significant differences among feeding treatments $(P<0.001$, a posteriori Tukey's test). F, fed; S, starved; FF, fed during the entire experiment; FS, fed until $14 \mathrm{DAH}$ and then starved; SF, starved until $14 \mathrm{DAH}$ and then fed; SS, starved during the entire experiment.

enormous recovery capability of the species. The results suggest that the availability of food following a period of starvation may trigger larval metabolism and cellular division.

The low condition of FF larvae could imply that the amount or quality of food was insufficient and could have had negative effects on condition. Another possible explanation could be that triggering metabolism in FF larvae takes longer and these larvae could have achieved a higher mean RDR in subsequent days, but this was not observed because the experiment ended on Day 21. Finally, a significant decay of larval condition was observed in the FS group, highlighting the vulnerability of advanced developmental stages to a lack of available food.

$P$. lineatus adults have been widely used as a biological model in biochemical assays to test the effect of different chemicals, pollutants or anthropogenic activities in the wild or 
in captivity assays (Camargo and Martinez 2006; Winkaler et al. 2007; Pereira Maduenho and Martinez 2008). Recently, Araújo and Rosa (2017) studied the effects of different diets on the growth, survival and stress responses of $P$. lineatus larvae. Nevertheless, as far as we know, there are no studies of nutritional condition of early developmental stages of $P$. lineatus.

Variations in the hydrological regime of the Paraná River could produce different degrees of connection between the main channel and flood plain lakes, thus affecting larval drift through the main channel, eventually prolonging the starvation period to which they are exposed and finally affecting their survival chances, as well as probably the recruitment of the species. The present study provides the necessary laboratory calibration for future investigations using wild larvae that undergo, for example, extreme flooding events as well as dry periods of low river discharge. The present study represents an important starting point for understanding ontogenetic changes in DNA and RNA content and the performance of the RDR, demonstrating the great potential of this technique for further condition studies in P. lineatus larvae.

\section{Conclusion}

The results of the present study indicate that the RDR is affected by the feeding condition and is sensitive enough to promptly reflect changes in feeding condition in $P$. lineatus larvae. The RDR results are feasible for use in tank-reared larvae to improve rearing conditions by testing the effects of changes in breeding protocols or the type of food provided, thus reducing the probability of disease, enhancing the efficiency of larval foraging and finally improving larval survival. The technique can undoubtedly also be used to calibrate the different degrees of starvation detected in wild larvae, thus determining unfavourable environmental conditions, and, because larvae in a poor condition are more vulnerable to predation, could also help predict $P$. lineatus recruitment.

\section{Conflicts of interest}

The authors declare that they have no conflicts of interest.

\section{Acknowledgements}

The authors acknowledge G. J. Macchi for his constant assistance and comments that substantially improved this manuscript. Special thanks to D. R. Brown for his careful reading of the revised manuscript. The authors also thank Instituto Nacional de Investigación y Desarrollo Pesquero (INIDEP), Fondo para la Investigación Científica y Tecnológica (FONCyT) and CONICET for financial support. This is INIDEP Contribution no. 2061. The authors also thank the anonymous reviewers for their helpful and constructive comments that greatly contributed to improving this work.

\section{References}

Agostinho, A. A., De Vazzoler, A. E. A., Gomes, L. C., and Okada, O. (1993). Estratificación espacial y comportamiento de Prochilodus scrofa en distintas fases del ciclo de vida, en la planicie de inundación del alto río Paraná y embalse de Itaipú, Paraná, Brasil. Revue d'Hydrobiologie Tropicale 26, 79-90.

Araújo, F. G., and Rosa, P. V. (2017). Docosahexaenoic acid (C22:6n-3) alters cortisol response after air exposure in Prochilodus lineatus (Valenciennes) larvae fed on enriched Artemia. Aquaculture Nutrition 23(6), 1216-1224. doi:10.1111/ANU.12490
Baigún, C., Puig, A., Minotti, P. G., Kandus, P., Quintana, R., Vicari, R., Bo, R., Oldani, N., and Nestler, J. (2008). Resource use in the Paraná River delta (Argentina): moving away from an ecohydrological approach? Ecohydrology \& Hydrobiology 8, 245-262. doi:10.2478/ V10104-009-0019-7

Baigún, C., Minotti, P., and Oldani, N. (2013). Assessment of sábalo (Prochilodus lineatus) fisheries in the lower Paraná River basin (Argentina) based on hydrological, biological, and fishery indicators. Neotropical Ichthyology 11, 199-210. doi:10.1590/S1679-62252013000100023

Bailey, K. M., Canino, M. F., Napp, J. N., Spring, S. M., and Brown, A. L. (1995). Contrasting years of prey levels, feeding conditions and mortality of larval walleye pollock Theragra chalcogramma in the western Gulf of Alaska. Marine Ecology Progress Series 119, 11-23. doi:10.3354/ MEPS119011

Bonetto, A. A. (1986). Fish of the Paraná system. In 'The Ecology of River Systems'. (Eds B. R. Davies and K. F. Walker.) pp. 573-588. (Dr. W. Junk Publishers: Dordrecht, Netherlands.)

Bonetto, A. A., Cannon Veron, M., and Roldán, D. (1981). Nuevos aportes al conocimiento de las migraciones de peces en el río Paraná. Ecosur 8 , 29-40.

Brown, D. R., and Fuentes, C. M. (2010). Daily increments in otoliths of sábalo (Prochilodus lineatus) larvae. Journal of Applied Ichthyology 26, 123-125. doi:10.1111/J.1439-0426.2009.01373.X

Buckley, L. (1984). RNA/DNA ratio: an index of larval fish growth in the sea. Marine Biology 80, 291-298. doi:10.1007/BF00392824

Buckley, B. A., Caldarone, E. M., and Ong, T.-L. (1999). RNA-DNA ratio and other nucleic acid-based indicators for growth and condition of marine fishes. Hydrobiologia 401, 265-277. doi:10.1023/A:1003798613241

Bulow, F. J. (1970). RNA-DNA ratios as indicators of recent growth rates of a fish. Journal of the Fisheries Research Board of Canada 27, 2343-2349. doi:10.1139/F70-262

Caldarone, E. M., Wagner, M., St. Onge-Burns, J., and Buckley, L. J. (2001). Protocol and guide for estimating nucleic acids in larval fish using a fluorescence microplate reader. Reference Document 11. (Northeast Fisheries Science Center.) Available at https://www.nefsc.noaa.gov/ nefsc/publications/crd/crd0111/crd0111.pdf [Verified 8 November 2017].

Caldarone, E. M., Clemmesen, M. C., Berdalet, E., Miller, T. J., Folkvord, A., Holt, G. J., Olivar, M. P., and Suthers, I. M. (2006). Intercalibration of four spectrofluorometric protocols for measuring RNA:DNA ratios in larval and juvenile fish. Limnology and Oceanography, Methods 4, 153-163. doi:10.4319/LOM.2006.4.153

Camargo, M. M. P., and Martinez, B. R. (2006). Biochemical and physiological biomarkers in Prochilodus lineatus submitted to in situ tests in an urban stream in southern Brazil. Environmental Toxicology and Pharmacology 21, 61-69. doi:10.1016/J.ETAP.2005.07.016

Chícharo, L., and Chícharo, M. A. (1995). The DNA/RNA ratio as a useful indicator of the nutritional condition in juveniles of Ruditapes decussatus. Scientia Marina 59, 95-101.

Chícharo, M. A., and Chícharo, L. (2008). RNA:DNA ratio and other nucleic acid derived indices in marine ecology. International Journal of Molecular Sciences 9, 1453-1471. doi:10.3390/IJMS9081453

Clemmesen, C. (1994). The effect of food availability, age or size on the RNA/DNA ratio of individually measured herring larvae: laboratory calibration. Marine Biology 118, 377-382. doi:10.1007/BF00350294

Dahlhoff, E. P. (2004). Biochemical indicators of stress and metabolism: applications for marine ecological studies. Annual Review of Physiology 66, 183-207. doi:10.1146/ANNUREV.PHYSIOL.66.032102.114509

Diaz, M. V., and Pájaro, M. (2012). Protocolo para la determinación de ácidos nucleicos en larvas de peces. INIDEP Technical report 20. Instituto Nacional de Investigación y Desarrollo Pesquero, Mar del Plata, Buenos Aires, Argentina.

Diaz, M. V., Olivar, M. P., and Macchi, G. J. (2014). Larval condition of Merluccius hubbsi (Marini, 1933) in the northern Patagonian spawning 
ground. Fisheries Research 160,60-68. doi:10.1016/J.FISHRES.2013. 11.009

Espinach Ros, A., and Sánchez, R. P. (2006). Proyecto de evaluación del recurso sábalo en el Paraná. Informe de los resultados de la primera etapa (2005-2006) y medidas de manejo recomendadas. Serie Pesca y Acuicultura: Estudios e Investigaciones Aplicadas 1, Secretaría de Agricultura Ganadería, Pesca y Alimentación, Buenos Aires, Argentina. Available at https://www.agroindustria.gob.ar/sitio/areas/pesca_continental/informes/baja/index.php [Verified 7 November 2017].

Espinach Ros, A., Sverlij, S., Amestoy, F., and Spinetti, M. (1998). Migration pattern of the sábalo Prochilodus lineatus (Pisces, Prochilodontidae) tagged in the lower Uruguay River. Verhandlungen des Internationalen Verein Limnologie 26, 2234-2236.

Ferron, A., and Leggett, W. C. (1994). An appraisal of condition measures for marine fish larvae. Advances in Marine Biology 30, 217-303. doi:10.1016/S0065-2881(08)60064-4

Foley, C. J., Bradleyc, D. L., and Hööka, T. O. (2016). A review and assessment of the potential use of RNA:DNA ratios to assess the condition of entrained fish larvae. Ecological Indicators 60, 346-357. doi:10.1016/J.ECOLIND.2015.07.005

Folkvord, A., Ystanes, L., and Moksness, E. (1996). RNA:DNA ratios and growth of herring (Clupea harengus) larvae reared in mesocosms. Marine Biology 126, 591-602. doi:10.1007/BF00351326

Fonseca, V. F., Vinagre, C., and Cabral, H. N. (2006). Growth variability of juvenile soles Solea solea and Solea senegalensis, and comparison with RNA:DNA ratios in the Tagus estuary, Portugal. Journal of Fish Biology 68, 1551-1562. doi:10.1111/J.0022-1112.2006.001042.X

Fuentes, C. M. (1998). Deriva de larvas de Sabalo, Prochilodus lineatus (Valenciennes, 1847) y otras especies de peces de interés comercial, en el Río Paraná Inferior. Ph.D. Thesis, Buenos Aires University, Buenos Aires, Argentina.

Fuentes, C. M., Gómez, M. I., Brown, D. R., Arcelus, A., and Espinach Ros, A. (2016). Downstream passage of fish larvae at the Salto Grande dam on the Uruguay River. River Research and Applications 32, 1879-1889. doi:10.1002/RRA.3030

Gómez, M. I., Sánchez, S., and Fuentes, C. M. (2014). Shrinkage of Prochilodus lineatus (Valenciennes, 1847) larvae preserved in either ethyl-alcohol or formalin in relation to their developmental stage and feeding condition. Journal of Applied Ichthyology 30, 140-144. doi:10.1111/JAI.12308

Gwak, W. S., Tsusaki, T., and Tanaka, M. (2003). Nutritional condition, as evaluated by RNA/DNA ratios, of hatchery-reared Japanese flounder from hatch to release. Aquaculture 219, 503-514. doi:10.1016/S00448486(02)00651-8

Hopkins, K. D. (1992). Reporting fish growth: a review of the basics. Journal of the World Aquaculture Society 23, 173-179. doi:10.1111/ J.1749-7345.1992.TB00766.X

Houde, E. D., and Zastrow, C. E. (1993). Ecosystem- and taxon-especific dynamic and energetics properties of larval fish assemblages. Bulletin of Marine Science 53, 290-335.

Hunter, J. R. (1981). Feeding ecology and predation of marine fish larvae. In 'Marine Fish Larvae. Morphology, Ecology and Relation to Fisheries'. (Ed. R. Lasker.) pp. 33-77. (Washington Press: Seattle, WA, USA.)

Kalous, L., The Bui, A., Petrtyl, M., Bohlen, J., and Chaloupkova, P. (2012) The South American freshwater fish Prochilodus lineatus
(Actinopterygii: Characiformes: Prochilodontidae): new species in Vietnamese aquaculture. Aquaculture Research 43, 955-958. doi:10. 1111/J.1365-2109.2011.02895.X

Ma, Z., Zheng, P., Guo, H., Zhang, N., Wang, L., Jiang, S., Qin, J. G., and Zhang, D. (2015). Effect of weaning time on the performance of Trachinotus ovatus (Linnaeus 1758) larvae. Aquaculture Nutrition 21, 670-678. doi:10.1111/ANU.12183

Malzahn, A. M., Clemmesen, C. M., and Rosenthal, H. (2003). Temperature effects on growth and nucleic acids in laboratory-reared larval coregonid fish. Marine Ecology Progress Series 259, 285-293. doi:10.3354/ MEPS259285

McGurk, M. D., Warburton, H. D., Galbraith, M., and Kusser, W. C. (1992) RNA-DNA ratio of herring and sand lance larvae from Port Moller, Alaska: comparison with prey concentration and temperature. Fisheries Oceanography 1, 193-207. doi:10.1111/J.1365-2419.1992.TB00038.X

Olivar, M. P., Diaz, M. V., and Chícharo, M. A. (2009). Tissue effect on RNA:DNA ratios of marine fish larvae. Scientia Marina 73, 171-182. doi:10.3989/SCIMAR.2009.73S1171

Paolucci, E. M., Cataldo, D. H., Fuentes, C. M., and Boltovskoy, D. (2007). Larvae of the invasive species Limnoperna fortunei (Bivalvia) in the diet of fish larvae in the Paraná River, Argentina. Hydrobiologia 589, 219-233. doi:10.1007/S10750-007-0734-2

Pereira Maduenho, L., and Martinez, C. B. R. (2008). Acute effects of diflubenzuron on the freshwater fish Prochilodus lineatus. Comparative Biochemistry and Physiology - C. Toxicology \& Pharmacology $\mathbf{1 4 8}$, 265-272. doi:10.1016/J.CBPC.2008.06.010

Quirós, R., and Baigún, C. (1985). Fish abundance related to organic matter in the Plata River Basin, South America. Transactions of the American Fisheries Society 114, 377-387. doi:10.1577/1548-8659(1985) $114<377$ :FARTOM $>2.0 . \mathrm{CO} ; 2$

Robinson, S. M., and Ware, D. (1988). Ontogenetic development of growth, rates in larval Pacific herring, Clupea harengus pallasi, measured with RNA/DNA ratios in the Strait of Georgia, British Columbia. Canadian Journal of Fisheries and Aquatic Sciences 45, 1422-1429. doi:10.1139/ F88-166

Sverlij, S. B., Espinach Ros, A., and Orti, G. (1993). Sinopsis de los datos biológicos y pesqueros del sábalo Prochilodus lineatus (Valenciennes, 1847). FAO Sinopsis sobre la Pesca 154, FAO, Rome, Italy.

Tanaka, Y., Satoh, K., Yamada, H., Takebe, T., Nikaido, H., and Shiozawa, S. (2008). Assessment of the nutritional status of field-caught larval Pacific bluefin tuna by RNA/DNA ratio based on a starvation experiment of hatchery-reared fish. Journal of Experimental Marine Biology and Ecology 354, 56-64. doi:10.1016/J.JEMBE.2007.10.007

Uriarte, I., and Balbontín, F. (1987). Caracterización del estado de hambruna en las larvas de sardina Sardinops sagax musica (Pisces, Clupeiformes) mediante criterios morfométricos e histológicos. Revista de Biología Marina 23, 77-106.

Winkaler, E. U., Santos, T. R. M., Machado-Neto, J. G., and Martinez, C. B. R. (2007). Acute lethal and sublethal effects of neem leaf extract on the neotropical freshwater fish Prochilodus lineatus. Comparative Biochemistry and Physiology - C. Toxicology \& Pharmacology 145, 236-244. doi:10.1016/J.CBPC.2006.12.009

Yandi, I., and Altinok, I. (2015). Defining the starvation potential and the influence on RNA/DNA ratios in horse mackerel (Trachurus mediterraneus) larvae. Helgoland Marine Research 69, 25-35. doi:10.1007/ S10152-014-0414-3 